\title{
Langerhans cell histiocytosis in cervical node in an adult female - a case report
}

\author{
Catherine Lalmuanawmi, Jayanta Das, Yumkhaibam S. Devi, Laishram J. Singh
}

Department of Radiotherapy, Regional Institute of Medical Sciences, Imphal - 795004, India

\begin{abstract}
Abstrak
Laporan kasus ini melaporkan histiositosis sel Langerhans (LCH) pada seorang perempuan berumur 58 tahun, yang datang dengan adenopati servikal bilateral, tanpa keluhan lainnya. Pemeriksaan klinik tidak menemukan kelainan lain, kecuali adenopati. Pemeriksaan histopatologi menunjukkan histiositosis sel Langerhans pada kelenjar getah bening. Akhir kata, LCH adalah penyakit yang jarang, dengan berbagai penampilan klinik, termasuk adenopati servikal. Diagnosis pasti dengan pemeriksaan histopatologi. Pada penderita LCH dewasa yang hanya menampilkan adenopati servikal, observasi merupakan pilihan penanganan yang efektif, karena kemungkinan terjadinya regresi spontan. (Med J Indones. 2013;22:114-6)
\end{abstract}

\begin{abstract}
A case of Langerhans Cell Histiocytosis (LCH) in a 58 year old woman who presented with bilateral cervical adenopathy without any other complaints is reported. Clinical examination did not reveal any other positive finding except the adenopathy. Histopathological examination confirmed the node to be Langerhans cell histiocytosis. In conclusion, LCH is a rare disease with varied clinical presentation, including cervical adenopathy. Diagnosis should be confirmed by histopathological examination of biopsy specimen. Observation may be an effective management strategy in cases of adult LCH with cervical adenopathy as the only symptom, due to its possible spontaneous regression. (Med J Indones. 2013;22:114-6)
\end{abstract}

Keywords: Langerhans cell histiocytosis

Langerhans cell histiocytosis $(\mathrm{LCH})$ is an uncommon disease of unknown etiology, ${ }^{1}$ usually affecting children. In adults it occurs in limited form. The pathogenesis is ill understood; whether it is a reactive process or neoplastic is still not defined. Spontaneous resolution occurs in 10$20 \%$ of patients and hence initial period of observation is often advisable. ${ }^{2} \mathrm{LCH}$ is the preferred terminology over histiocytosis $\mathrm{X}$, eosinophilic granuloma, Abt-LettererSiwe disease, Hand-Schuller-Christian disease, and reticuloendotheliosis.

\section{CASE REPORT}

A 58 year old, unmarried woman reported with complaints of diminution in hearing and ringing of right ear for two years, swelling of right neck, which later involved the left side for two years, and low backache that was off and on for one year. She had a history of diabetes mellitus and hypertension for three years and is on regular treatment. She smoked hookah for 5-6 years, and quitted smoking two years ago.

Her Karnofsky performance status was $90 \%$ with no pallor, icterus, dehydration, edema, and cyanosis. The vital signs were within normal limits. Oropharynx and oral cavity were normal. There was no midline swelling. Systemic examinations were within normal limit. Neck showed multiple bilateral neck nodes at level II-V, which were non tender, rubbery with smooth margins and smooth skin over the swellings; the largest measuring $2 \times 2 \mathrm{cms}$.
Investigations showed normal haemogram and normal blood biochemical values. The serum LDH showed a value of $378 \mathrm{IU} / \mathrm{L}$, serum calcium was $9.1 \mathrm{mg} / \mathrm{dL}$, urine showed a specific gravity of 1.004. Imaging showed a normal chest and abdomen. However, the bones showed multiple punched out lesions at parietal, frontal, and, occipital bones (Figure 1). Pure tone audiometry showed minimal conduction hearing loss on left side and profound hearing loss on right side. Bone marrow showed normal reactive marrow with $4 \%$ plasma cells. Cervical lymph node biopsy showed Langerhans cell histiocytosis (Figure 2). Immunohistochemistry staining was CD1a positive. She was put on Zoledronic acid injection at three weekly interval for six cycles along with oral prednisolone 20 mg for day 1-7, alternate week. At the time of her last follow up, two years later after completing nine months of treatment, she was doing fine. Her bony lesions have completely regressed and neck node was just palpable.

\section{DISCUSSION}

Langerhans cell histiocytosis is a dendritic cell disorder. ${ }^{3,4}$ LCH results from clonal proliferation of immunophenotypically and functionally immature, morphologically rounded LCH cells. ${ }^{3}$ Presence of either CD1a cell surface antigen or the finding of Birbeck granules in the lesional cells are valuable diagnostic adjuncts. ${ }^{1,5}$

There is 1-2 adult $\mathrm{LCH} /$ million population. ${ }^{6} \mathrm{LCH}$ may involve single organ (single-system LCH), single 


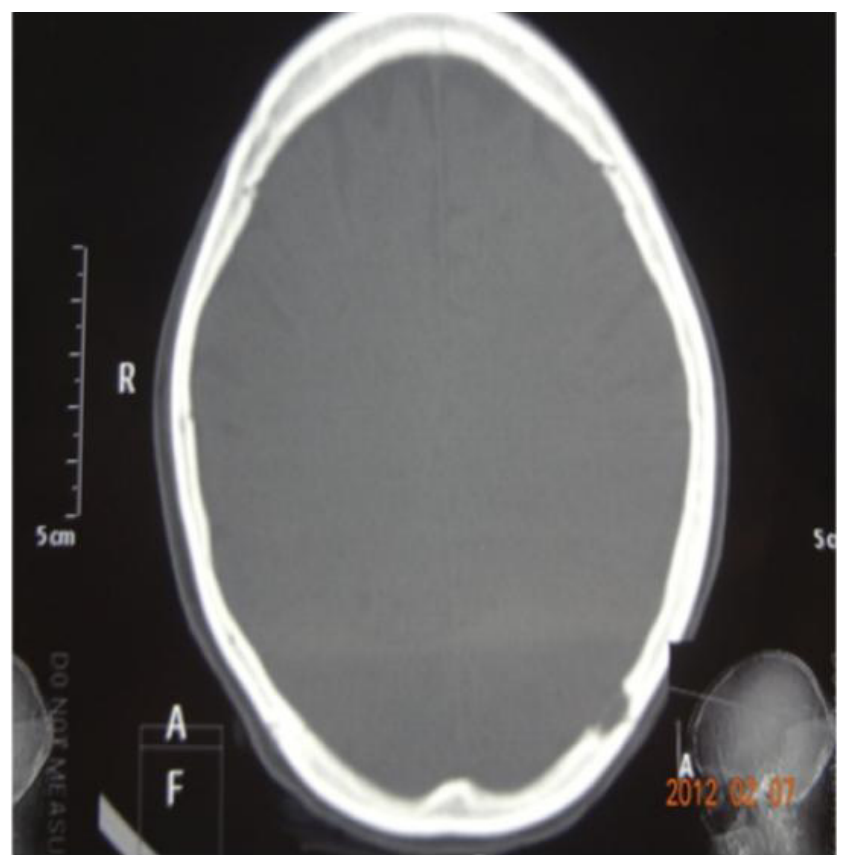

Figure 1. Punched out lesions on occipital region of skull

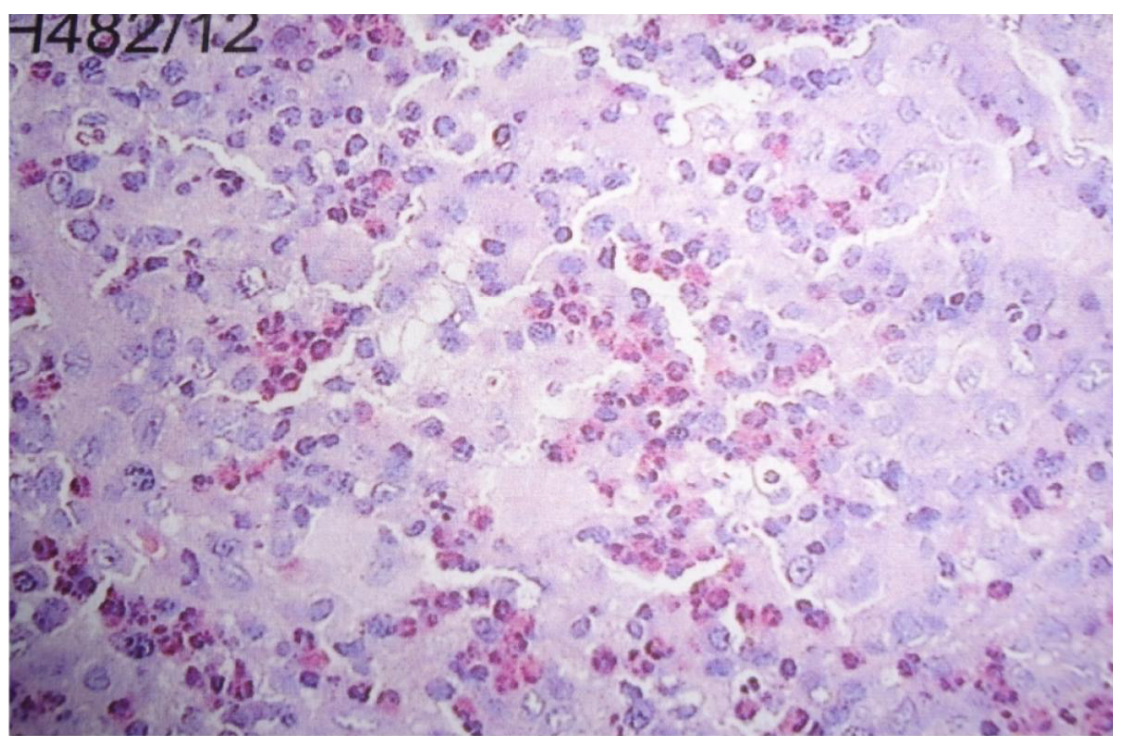

Figure 2. Langerhans' cells with grooved nuclei in sheets with numerous eosinophils $(H \& E$ Stain, $X 40)$

site (unifocal), multiple sites (multifocal) or it may involve multiple organs (multisystem LCH). Signs and symptoms in order of decreasing frequency includes dyspnea or tachypnea, polydipsia and polyuria, bone pain, lymphadenopathy, weight loss, fever, gingival hypertrophy, ataxia, memory problems, skin rash, scalp nodules, soft tissue swelling near bone lesions, and hepatosplenomegaly. Most common involved organs are lung, bone, and skin. Patients who present with isolated diabetes insipidus (DI) should be observed for onset of other symptoms or signs characteristic of $\mathrm{LCH}$ since $80 \%$ of them may have involvement of other organ systems. ${ }^{7}$
Cervical nodes are most frequently involved as soft/hard matted groups with accompanying lymphedema. Pulmonary LCH is more common in smokers, presenting with a dry cough, dyspnoea or chest pain. Spontaneous remission can occur with cessation of smoking. Single bone lesion is usually treated by curettage with or without intra-lesional corticosteroids. Localised skin lesions can be treated by surgical excision, topical steroids/ intralesional steroids, psoralen, and long wave ultraviolet radiation. Severe skin lesions are treated with systemic therapies like - methotrexate, thalidomide, 
interferon alfa $(\operatorname{IF} \alpha)$ or a combination of them. Etoposide, cladribine have been used effectively in multi-system LCH. Bisphosphonate controls bone pain in multifocal bone involvement. In view of the increased toxicity of chemotherapy in adults, bisphosphonate therapy could be used prior to chemotherapy in multifocal bone disease. Low dose radiation therapy can be given when chemotherapy fails or there is impending neurological deficits, vertebral body lesion or visual problems from orbital lesions.

In conclusion, Langerhans cell histiocytosis is a rare disease with varied clinical presentation. Presentation with cervical adenopathy is not common. Diagnosis depends on identification of characteristic immunohistochemical or ultrastructural features in the biopsy specimen. Observation may be an effective management strategy in cases of adult LCH who present with cervical adenopathy only due to its possible spontaneous regression. LCH may be suspected in dealing with cervical lymphadenopathy in adult population.

\section{REFERENCES}

1. Pritchard J, Malone M. Histiocyte disorders. In: Peckham M, Pinedo H, Veronesi U, editors. Oxford textbook of oncology. $2^{\text {nd }}$ edition. Oxford: Oxford University Press; 2001.p.2457-75.

2. Broadvent V, Pritchard J. Histiocytosis X-current controversies. Arch Dis Child. 1985;60(7):605-7.

3. Laman JD, Leenen PJ, Annels NE, Hogendoorn PC, Egeler RM. Langerhans-cell histiocytosis 'insight into DC biology’. Trends Immunol. 2003;24(4):190-6.

4. Jaffe R. The diagnostic histopathology of Langerhans cell histiocytosis. In: Weitzman S, Egeler R M, editors. Histiocytic disorders of children and adults. United Kingdom: Cambridge University Press; 2005.p.14-39.

5. Elsheikh T, Silverman JF, Wakely PE Jr, Holbrook CT, Joshi VV. Fine needle aspiration cytology of Langerhans cell histiocytosis (eosinophilic granuloma) of bone in children. Diagn Cytopathol. 1991;7(3):261-6.

6. Baumgartner I, von Hochstetter A, Baumert B, Luetolf U, Follath F. Langerhans-cell histiocytosis in adults. Medical \& Pediatric Oncology. 1997;28:9-14.

7. Kaltsas GA, Powles TB, Evanson J, et al. Hypothalamopituitary abnormalities in adult patients with Langerhans cell histiocytosis: clinical, endocrinological, and radiological features and response to treatment. J Clin Endocrinol Metab. 2000;85(4):1370-6. 